UDC 602.1:53.082.9 (045)

\title{
DIFFERENT TYPES OF BIOSENSORS AND THEIR FEATURES
}

\author{
D.V. SIEDIUKO, Y.I. HALUZINSKA \\ National Aviation University, Kyiv
}

Biosensor technology is a powerful alternative to conventional techniques. Biosensors are analytical devices that respond selectively to analytes in an appropriate sample and convert their concentration into an electrical signal via a combination of a biological recognition system and an electrochemical, optical or other transducer. Different types of biosensors are described in this article. The main features of them are compared. Also mentioned the main areas of its application.

Key words: biosensors, transducer, calorimetric, potentiometric, amperometric, optical and acoustic wave biosensors.

Introduction. Determining analyte concentrations is essential for a wide range of applications, including high-throughput drug screening, disease diagnosis and treatment, quality control, and environmental monitoring. Industrial instrumentation for analysis is scarce and often limited to $\mathrm{pH}$ and conductivity. In most cases, accurate analyses of biological materials are expensive and need to be performed in external laboratories equipped with more sophisticated instrumentation. Most of these analyses require previous purification that require too much time relative to the processing time, making their on-line implementation impossible for control purposes. However, in living organisms, biological components like antibodies and enzymes work as natural sensing and controlling "devices". The ability of isolating and purifying these proteins and other biological elements such as cells or organelles has allowed their integration with physicochemical transduction devices to produce biosensors [1]. 
Biosensor is a branch of analytical biotechnology. A biosensor is a device incorporating a biological sensing element either intimately connected to or integrated within a transducer. The usual aim is to produce a digital electronic signal which is proportional to the concentration of a specific chemical or set of chemicals [2].

The first biosensor was described in 1962 by Clark and Lyons who immobilized glucose oxidase (GOD) on an amperometric oxygen electrode surface semipermeable dialysis membrane in order to quantify glucose concentration in a sample directly. They described how "to make electrochemical sensors $(\mathrm{pH}$, polarographic, potentiometric or conductometric) more intelligent" by adding "enzyme transducers as membrane enclosed sandwiches" [3, 4].

Structure of biosensors system. A biosensor system typically consists of a biorecognition component, biotransducer component, and electronic system which include a signal amplifier, processor, and display [5] (Fig .1).

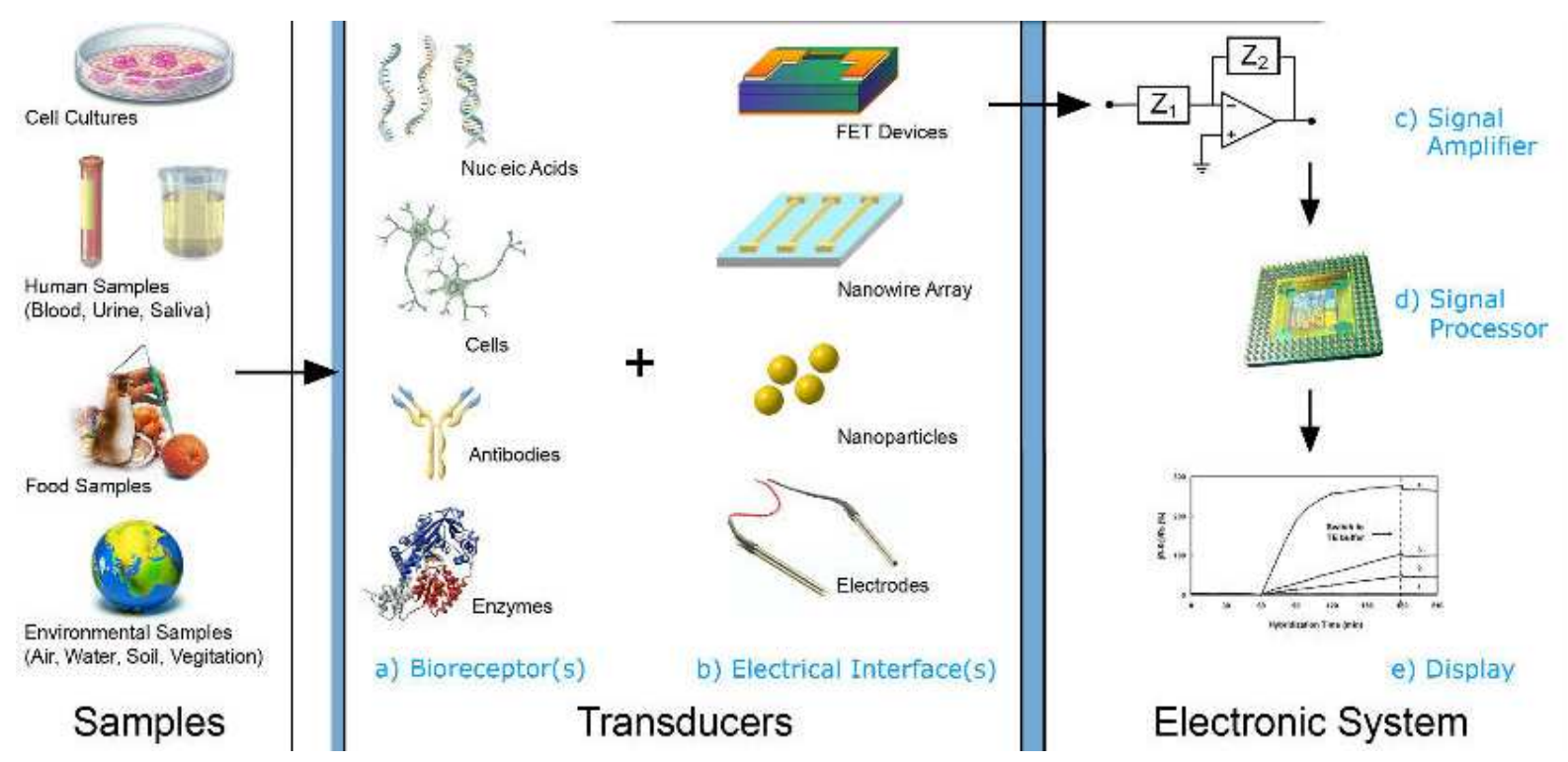

Fig. 1. Structural elements of biosensor

The recognition component, often called a bioreceptor, uses biomolecules from organisms or receptors modeled after biological systems to interact with the analyte of interest. This interaction is measured by the biotransducer which outputs a measurable signal proportional to the presence of the target analyte in the sample. 
The general aim of the design of a biosensor is to enable quick, convenient testing at the point of concern or care where the sample was procured (Fig. 2) [6].

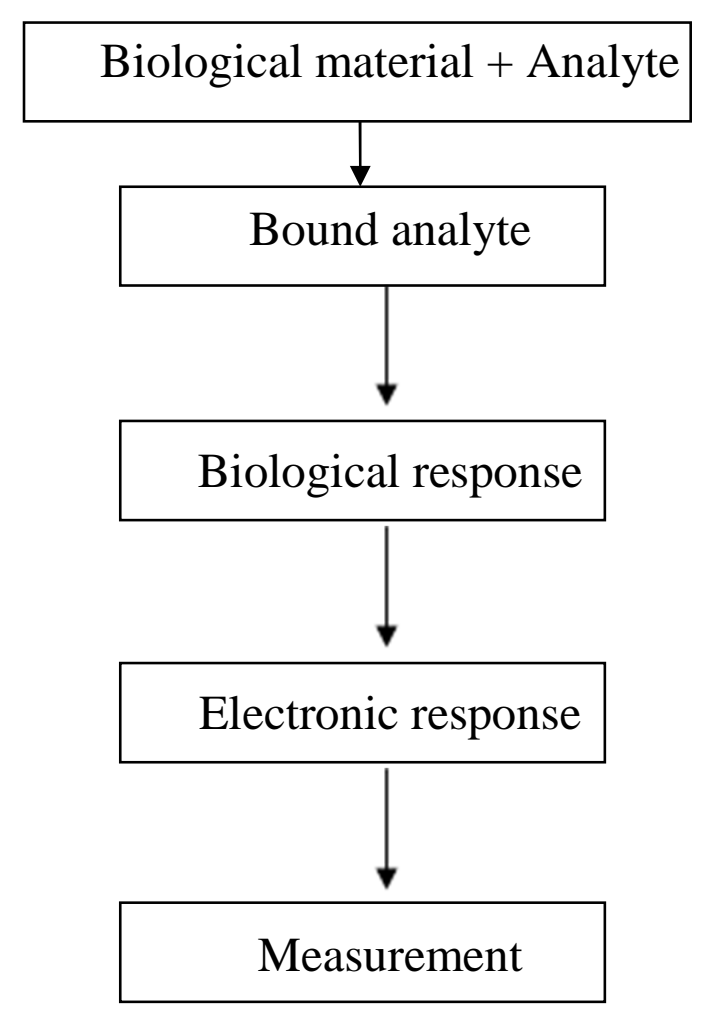

Fig. 2. Scheme of biosensor operating

The biological materials usually are enzymes, but nucleic acids, antibodies, lectins, whole cells, entire organs or tissue slices are also used. The biological component of biosensor performs two key functions: it specifically recognizes the analyte (compound whose concentration is to be determined) and interacts with it in such a manner, which produces some physical change detectable by the transducer. These properties of the biological component impart on the biosensor specificity, sensitivity and the ability to detect and measure the analyte $[5,7]$.

The nature of interaction between the analyte and the biological material may be of two types:

- the analyte may be converted into a new chemical molecule (by enzymes; such biosensors are called catalytic biosensors);

-the analyte may simply bind to the biological material present on the biosensor (e.g., to antibodies, nucleic acids; these biosensors are known as affinity biosensors). 
The transducer detects and measures this change and converts it into an electrical signal. This signal is necessarily very small, and is amplified by an amplifier before it is fed into the microprocessor. The signal is then processed and interpreted, and is displayed in suitable units [8].

Types of biosensor. Biosensors can be grouped according to their transduction element. There are six types of biosensors: calorimetric, potentiometric, amperometric, optical and acoustic wave biosensors (Table 1).

Table 1

\section{Classification of biosensors}

\begin{tabular}{|c|c|l|}
\hline $\begin{array}{c}\text { Types of } \\
\text { biosensor(detection } \\
\text { device or transducer) }\end{array}$ & $\begin{array}{c}\text { Biological } \\
\text { component }\end{array}$ & \multicolumn{1}{|c|}{ Type of change detected } \\
\hline Amperometric & Enzymes & Redox reaction (releasing of e-) \\
\hline Potentiometric & Enzymes & Releasing or consumption of gas \\
\hline Calorimetric (thermal ) & Enzymes & Temperature \\
\hline Optical & $\begin{array}{c}\text { Enzymes, } \\
\text { antibody, } \\
\text { DNA/RNA }\end{array}$ & $\begin{array}{l}\text { Fluorescence or absorbance or } \\
\text { optical properties of biosensor } \\
\text { surface }\end{array}$ \\
\hline Acoustic wave & Antibody & $\begin{array}{l}\text { Resonant frequency of certain } \\
\text { crystals due to change in mass }\end{array}$ \\
\hline
\end{tabular}

Amperometric biosensors. In amperometric transducers, the potential between the two electrodes is set and the current produced by the oxidation or reduction of electroactive species is measured and correlated to the concentration of the analyte of interest. Most electrodes are made of metals like platinum, gold, silver, and stainless steel, or carbon-based materials that are inert at the potentials at which the electrochemical reaction takes place [9]. The simplest amperometric biosensors use the Clark oxygen electrode, which determines the reduction of $\mathrm{O}_{2}$ present in the sample (analyte) solution [4].

Calorimetric biosensors are also called thermometric biosensors or thermal biosensors. Many enzyme catalyzed reactions produce heat (exothermic). Calorimetric biosensors measure the change in temperature of the solution containing 
the analyte, following enzyme action and interpret it in terms of the analyte concentration in the solution.

The difference in the temperatures is usually a fraction of one degree Celsius, but it is possible to detect differences as low as $0.0001{ }^{\circ} \mathrm{C}$. It is imperative to eliminate the effects of environment on the heat changes produced by the reaction. Therefore, the reaction is confined within a heat insulated box, and the analyte stream is passed through a heat exchanger.

The greatest disadvantage is the need to maintain the temperature of the sample stream at a constant, say $\pm 0.01^{\circ} \mathrm{C}$, temperature. The sensitivity $\left(10^{-4} \mathrm{M}\right)$ and the range $\left(10^{-4}-10^{-2} \mathrm{M}\right)$ of such biosensors are quite low for most applications. The sensitivity can be increased by using two or more enzymes of the pathway in the biosensor to link several reactions to increase the heat output. Alternatively, multifunctional enzymes may be used [10].

Potentiometric biosensors make use of ion-selective electrodes in order to transduce the biological reaction into an electrical signal. In the simplest terms this consists of an immobilized enzyme membrane surrounding the probe from a $\mathrm{pH}$ meter. The signal is measured as the potential difference (voltage) between the working electrode and the reference electrode. The working electrode's potential must depend on the concentration of the analyte in the gas or solution phase. The reference electrode is needed to provide a defined reference potential [9].

Optical biosensors that exploit surface plasmon resonance, waveguides and resonant mirrors have been used widely over the past decade to analyse biomolecular interactions. These sensors allow the determination of the affinity and kinetics of a wide variety of molecular interactions in real time, without the need for a molecular tag or label. Advances in instrumentation and experimental design have led to the increasing application of optical biosensors in areas of drug discovery, including target identification, ligand fishing, assay development [11]. SPR measurement is based on the detection of the attenuated total reflection of light in a prism with one side coated with a metal. When p-polarized incident light passes through the prism and strikes the metal at an adequate angle, it induces a resonant charge wave at the 
metal/dielectric interface that propagates a few microns. The total reflection is measured with a photodetector, as a function of the incident angle [12].

Acoustic Wave Biosensors are also called piezoelectric biosensors. Electroacoustic devices used in biosensors are based on the detection of a change of mass density, elastic, viscoelastic, electric, or dielectric properties of a membrane made of chemically interactive materials in contact with a piezoelectric material. Certain crystals contain positive and negative charges, which separate, when they are subjected to stress. This generates an electric field, which is called piezoelectric effect $[13,14]$.

Such piezoelectric crystals can be used to assay the mass of analyte that binds to the biological component immobilized on the crystal surface. For example, cocaine in gas phase is detected by attaching cocaine antibodies to the surface of a piezoelectric crystal. This biosensor changes resonant frequency by about $50 \mathrm{~Hz}$ for one part per billion cocaine in the sample atmosphere. The biosensor can be reused after flushing it for a few seconds with clean air.

One of the major disadvantages of these biosensors is the difficulty in using them to determine analytes in solution. One way is to determine analytes using antigenantibody interaction. In such cases, the crystal surface is coated with antibodies, which bind to the complementary antigen present in the sample solution. A piezoelectric biosensor has been developed for the detection of enterobacteria $[15,16]$.

Comparison of different types of biosensors. The different types of biosensors differ from each other for several features. The main criteria of biosensors are sensitivity, response time, accuracy, life time, reliability and cost. Accuracy of the biosensor should be high for the detection of high substrate concentration. Sensitivity value of the electrode response per substrate concentration. Selectivity chemicals interference must be minimized for obtaining the correct result. Response time - is time necessary for obtaining of $95 \%$ of the response. The important differences among the various biosensors are summarized in Table 2 . 
Table 2

Comparison of different types of biosensors

\begin{tabular}{|c|c|c|c|c|c|}
\hline \multirow{2}{*}{ Criteria } & \multicolumn{5}{|c|}{ Type of biosensor } \\
\cline { 2 - 6 } & Amperometric & Potentiometric & Calorimetric & Optical & $\begin{array}{l}\text { Acoustic } \\
\text { wave }\end{array}$ \\
\hline Sensitivity & Medium & Medium & High & Low & Low \\
\hline $\begin{array}{c}\text { Response } \\
\text { time }\end{array}$ & Medium & Medium & Slow & Medium & Fast \\
\hline Accuracy & Medium & Medium & High & Medium & Low \\
\hline Life time & Limited & Limited & Limited & Limited & Limited \\
\hline Complexity & High & Medium & Very high & Medium & Low \\
\hline Reliability & High & Medium & High & Low & Low \\
\hline Cost & Low & Low & High & Low & Low \\
\hline
\end{tabular}

Application of biosensors. A biosensor has a wide range of applications in different fields. One of the major driving forces for the development of biosensors is biomedical diagnosis. The most popular example is glucose oxidase-based sensor used by individuals suffering from diabetes to monitor glucose levels in blood. Biosensors have found also potential applications in the agricultural and food industries. However, very few biosensors have been commercialized [9].

Industrial application: various manufacturing processes can be monitored by biosensors to provide assistance with regard to increase the quality and quantity of product obtained. It is used in the food industry to measure carbohydrates, alcohols and acids, for example, during quality control processes. The devices may also be used to check fermentation during the production of beer, yoghurt and soft drinks. Another important application is their use in detecting pathogens in fresh meat, poultry or fish [17].

Biosensors are used to check the quality of air and water. The devices can be used to pick up traces of organophosphates from pesticides or to check the toxicity levels of wastewater, for example [18].

Military application: it helps to detect explosives, drugs etc., aiding in defence of the people. Another breakthrough in the field of biosensors was the production of a 
product called 'smart skin'. It is a kind of biosensor which detects any chemical or biological attack nearby and warns the person using the same [5].

\section{CONCLUSIONS}

In this article we discussed various types of biosensors in detail. Biosensors based on the parameter measured can be classified as: amperometric, potentiometric, calorimetric, optical, acoustic, wave. Working principles, constructions, advantages, and applications of many biosensors was presented.

Comparison of different types of biosensors was based on such criteria as sensitivity, response time, accuracy, life time, reliability and cost. Biosensors have a variety of biomedical, environmental, industry and military applications

\section{REFERENCES}

1. De Corcuera J. I. R. Biosensors: Encyclopedia of agricultural, food, and biological engineering / De Corcuera J. I. R., Cavalieri R. P. - Florida: Biosensors, 2003. -124 p.

2. Saini S. Design and Development of Microcontroller Based Auto-Flow Assembly for Biosensor Application / Saini S., Suri C. // International Journal of Computer Applications. - 2010. - №12. - P. 26-28.

3. Biosensors and their principles / [Koyun A., Ahlatcolu E., Koca Y., Kara S.]. - London: A Roadmap of Biomedical Engineers and Milestones, 2012. - 108 p.

4. Yoo E.-H. Glucose biosensors: an overview of use in clinical practice / Yoo E.-H., Lee S.-Y. // Sensors. - 2010. - № 5. - P. 58-76.

5. Turner A. Biosensors: fundamentals and applications / Turner A., Karube I., Wilson G. S. - Bristol: Biomedical Engineers, 1987.- 78 p.

6. Vo-Dinh T. Biosensors and biochips: advances in biological and medical diagnostics / Vo-Dinh T., Cullum B. // Fresenius' journal of analytical chemistry. 2000. - № 7. - P. 540-551.

7. Turner A. P. Biosensors / Turner A. P. // Current opinion in biotechnology. 1994. - № 1. - P. 49-53.

8. Shanmugam S. Enzyme technology / Shanmugam S. - London: IK International Pvt Ltd, 2009. - 224 p. 
9. Mohanty S. P. Biosensors: a tutorial review / Mohanty S. P., Kougianos E. // Potentials, IEEE. - 2006. - № 2. - P. 35-40.

10. Danielsson B. Calorimetric biosensors / Danielsson B. // Journal of biotechnology. - 1990. - № 3. - P. 187-200.

11. Cooper M. A. Optical biosensors in drug discovery / Cooper M. A. // Nature Reviews Drug Discovery. - 2002. - № 7. - P. 515-528.

12. Lawrence Chris R. Surface plasmon resonance (SPR) for biosensing / Lawrence Chris R., Geddes N. - Brilon: Handbook of Biosensors and Electronic Noses. Medicine, Food and the Environment, 1997. - 168 p.

13. Lec R. M. Acoustic wave biosensors / Lec R. M., Lewin P. A. New York: Engineering in Medicine and Biology Society, 1998. - 784 p.

14. D’Amico A. Acoustic devices / D'Amico A., Di Natale C., Verona E. Newcastle: Handbook of Biosensors and Electronic Noses, 1997. - 223 p.

15. Drafts B. Acoustic wave technology sensors / Drafts B. // IEEE Transactions on Microwave Theory and Techniques. - 2001. - № 4. - P. 795-802.

16. Acoustic-Based Biosensors / [Durmuş N. G., Lin R. L., Kozberg M., Dermici D.,]. Dahn:Encyclopedia of Microfluidics and Nanofluidics, 2015. - 40 p.

17. Deshpande S. Biosensors and their potential use in food quality control: Applications of immunobiosensors and bioelectronics in food sciences and quality control / Deshpande S., Rocco R. // Food Technology. - 1994. - № 6. - P. 146-150.

18. Haron S. Optical biodetection of cadmium and lead ions in water / Haron S., Ray A. K. // Medical engineering \& physics. - 2006. - № 10. - P. 978-981.

\title{
РАЗЛИЧНЫЕ ТИПЫ БИОСЕНСОРОВ И ИХ ОСОБЕННОСТИ
}

\author{
Д. В. СЕДЮКО, Ю. И. ГАЛУЗИНСКАЯ
}

Национальный авиащионный университет, г. Киев

Биосенсорика является мощной альтернативой традицонным методам. Биосенсоры - аналитические устройства, которые реагируют на присутствие 
компонента в образие и превращают значение его конщентращии в сигнал, посредством объединения системы биологического распознавания $u$ электрохимического, оптического или другого преобразователя. В этой статье описаны различные типь биосенсоров. Указаны основные характеристики и их различия. Также рассмотрены основные направления применения биосенсоров.

Ключевые слова: биосенсор, датчик, калориметрический биосенсор, потенциометрический биосенсор, амперометрический биосенсор, оптический биосенсор, акустический биосенсор.

\title{
РІЗНІ ТИПИ БІОСЕНСОРІВ ТА ЇХ ОСОБЛИВОСТІ
}

\author{
Д. В. СЕДЮКО, Ю. І. ГАЛУЗІНСЬКА
}

Національний авіаиійний університет, м. Київ

Біосенсорика $\epsilon$ потужною альтернативою традиційним методам. Біосенсори - аналітичні пристрої, що реагують на присутність компонента в зразку і перетворюють значення його концентращиї в сигнал, за допомогою об'єднання системи біологічного розпізнавання і електрохімічного, оптичного або інших перетворювачів. У иій статті описані різні типи біосенсорів. Вказані основні характеристики та їх відмінності. Також розглянуті основні напрямки застосування біосенсорів.

Ключові слова: біосенсор, датчик, калориметрический біосенсор, потенціометричний біосенсор, амперометричний біосенсор, оптичний біосенсор, акустичний біосенсор. 